CHANNEL AND BANK STABILITY OF STANDING PINE CREEK AT STATE HIGHWAY 488 NEAR FREENY, LEAKE COUNTY, MISSISSIPPI

By D. Phil Turnipseed and K. Van Wilson, Jr.

U.S. GEOLOGICAL SURVEY

Open-File Report 92-112

Prepared in cooperation with the MISSISSIPPI STATE HIGHWAY DEPARTMENT

Jackson, Mississippi 
DEPARTMENT OF THE INTERIOR

MANUEL LUJAN, JR., Secretary

U.S. GEOLOGICAL SURVEY

Dallas L. Peck, Director

For additional information write to:

District Chief

U.S. Geological Survey

Suite 710, Federal Building

$100 \mathrm{~W}$. Capitol Street

Jackson, Mississippi 39269
Copies of this report can be purchased from:

U.S. Geological Survey Books and Open-File Reports Section Box 25425, Federal Center

Denver, Colorado 80225 


\section{CONTENTS}

Page

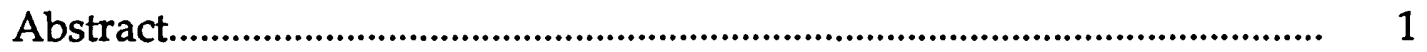

Introduction ...................................................................................... 2

Purpose and scope..................................................................................... 2

General description of Standing Pine Creek........................................ 2

Channel modifications to Standing Pine Creek.................................. 2

Acknowledgments....................................................................................... 4

Channel-bed stability ....................................................................................... 4

Profiles.................................................................................................. 4

Gradation analyses....................................................................................... $\quad 7$

Channel-bank stability ....................................................................................... 9

Evidence of widening ................................................................................ 9

Cross sectional evidence........................................................................ 9

Botanical evidence........................................................................... 9

Stability analyses .................................................................................. 10

Widening analyses.............................................................................. 15

Summary .............................................................................................. 15

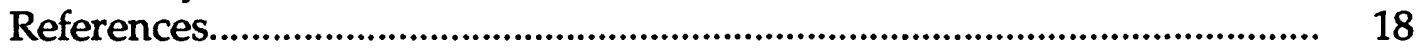

\section{ILLUSTRATIONS}

Figure 1. Map showing location of Standing Pine Creek at State Highway 488 near Freeny.........................................................

2. Channel-bed profiles in 1973, 1978, and 1987 for Standing Pine Creek

3. Channel-bed profiles for Standing Pine Creek in the vicinity of State Highway 488 near Freeny.......................... 6

4. Graph showing average channel-bed elevation for Standing Pine Creek at State Highway 488 near Freeny, 1958-91

5. Cross section showing critical failure surfaces for channel banks on Standing Pine Creek 100 feet upstream from State Highway 488 near Freeny, 1988...

6. Cross section showing critical failure surfaces for channel banks on Standing Pine Creek at State Highway 488 near Freeny, 1988 


\section{ILLUSTRATIONS--Continued}

Figure 7. Cross section showing critical failure surfaces for channel

Page banks on Standing Pine Creek 100 feet downstream from State Highway 488 near Freeny, 1988

8. Cross section showing estimates of near-future channel widening for Standing Pine Creek 100 feet upstream from State Highway 488 near Freeny, 1988

9. Cross section showing estimates of near-future channel widening for Standing Pine Creek 100 feet downstream from State Highway 488 near Freeny, 1988

\section{TABLES}

Table 1. Measured channel-bed elevation and change in channelbed elevation (outside of scour hole) on Standing Pine Creek at State Highway 488 near Freeny

2. Botanical data collected in 1988 on Standing Pine Creek in the vicinity of State Highway 488 near Freeny.

3. Dry bulk-unit weight and shear-strength properties of soils as determined from borehole tests on the right (east) bank of Standing Pine Creek about 120 feet downstream from State Highway 488 near Freeny 


\section{CONVERSION FACTORS AND VERTICAL DATUM}

$\begin{array}{lcl}\text { Multiply } & \text { By } & \text { To obtain } \\ \text { acre } & 4,047 & \text { square kilometer } \\ \text { foot }(\mathrm{ft}) & 0.3048 & \text { meter } \\ \text { foot per mile }(\mathrm{ft} / \mathrm{mi}) & 0.1894 & \text { meter per kilometer } \\ \text { pounds per square foot }\left(\mathrm{lb} / \mathrm{ft}^{2}\right) & 47.88 & \text { newtons per square meter } \\ \text { pounds per cubic foot }\left(\mathrm{lb} / \mathrm{ft}^{3}\right) & 157.09 & \text { newtons per cubic meter } \\ \text { mile (mi) } & 1.609 & \text { kilometer } \\ \text { square mile }\left(\mathrm{mi}^{2}\right) & 2.590 & \text { square kilometer }\end{array}$

Mississippi State Highway Department Datum: In this report, elevations are referenced to Mississippi State Highway Department Datum (MSHDD) -- a sitespecific datum. At this site, add 94.8 feet to elevations referenced to MSHDD to convert to the National Geodetic Vertical Datum of 1929 (NGVD of 1929)--a datum derived from a general adjustment of the first-order level nets of both the United States and Canada, formerly called Sea Level Datum of 1929. 


\section{DEFINITION OF TERMS}

Selected terms used in this report are defined below.

Angle of internal friction -angle of the plane of contact of soil particles with the horizontal at the point of sliding (shearing); angle whose tangent is the coefficient of friction between the soil particles (Cernica, 1982).

Channel-bed aggradation -filling in of the channel because streamflows are not sufficient to transport the material delivered from upstream channel-bed degradation (Simon and Hupp, 1986a).

Channel-bed degradation -headward erosion of the channel bed usually caused by increases in downstream channel gradient and crosssectional area by man (Simon and Hupp, 1986a).

Cohesion -attraction of adsorbed water and soil particles that produce a body, which holds together but deforms plastically at varying water contents (Sowers, 1979).

Dry bulk-unit weight -ratio of the weight of the soil solids to the volume of the soil sample (Das, 1984).

Factor of safety -ratio of the resisting force (shear strength of the soil) to the driving force (weight of the soil). If the resisting force is less than the driving force, the factor of safety is less than 1.0, and therefore, failure occurs (Huang, 1983).

Failure-block widths -the measured width of the failure block or the distance between affected stems of woody plants growing in bank material that has failed and fallen down slope and the existing top-bank edge (Hupp, 1987).

Iowa Borehole Shear Test -direct measure of shear strength of fine- to medium-grained soils insitu (from inside a borehole) (Handy, 1981).
Moisture content -ratio of the weight of the water present to the weight of the soil solids (Das, 1984).

Rotational failure -landslide along a surface of rupture that is concave upward. The exposed cracks are concentric in plan and concave toward the direction of movement (Huang, 1983).

Shear strength -capacity of a soil to resist shear; in terms of effective stress, it can be given by the equation:

where:

$$
s^{\prime}=c^{\prime}+\sigma^{\prime} \tan \phi^{\prime}
$$

$\sigma^{\prime}=$ effective normal stress on plane of shear

$c^{\prime}=$ cohesion or apparent cohesion of the soil; and

$\phi^{\prime}=$ angle of internal friction.

(Das, 1984).

Slough-line angle -angle attained by projecting the slope of failed blocks of soil mass (which represents a temporary angle of stability) to its intersection with the top of channel bank (flood-plain level). It is used to determine short-term (10-20 years) bank widening (Simon and Hupp, 1986b).

Temporary angle of stability the angle from the horizontal extended from the toe to the top of bank in which that bank at that given height is the most stable. It can be estimated by averaging the existing bank angle with the angle of internal friction of the bank material. (Spangler and Handy, 1973). 


\title{
CHANNEL AND BANK STABILITY OF STANDING PINE CREEK \\ AT STATE HIGHWAY 488 NEAR FREENY, LEAKE COUNTY, MISSISSIPPI
}

By D. Phil Turnipseed and K. Van Wilson, Jr.

\begin{abstract}
The channel bed of Standing Pine Creek at State Highway 488 near Freeny, Mississippi, was about 1 foot higher in 1991 than when the reach was channelized in 1973. Aggradation in this reach between 1973 and 1978 probably was greater than 1 foot because the reach of the channel downstream of State Highway 488 was dredged twice during that period. Aggradation since 1978 has been relatively small. From 1978 to 1991, bankfull channel widths remained about the same at the bridge and in the channel reach 500 to 6,000 feet downstream from the bridge but increased an average of about 15 feet in the channel reach 200 to 2,500 feet upstream of the bridge. The average channel-bed slope in the vicinity of State Highway 488 decreased from about 5.6 feet per mile in 1973 to about 2.8 feet per mile in 1987 . The channel-bed slope in 1991 seems to be about the same as that in 1987. Based on botanical evidence, most recent bank failures seem to have occurred during the April 1979 flood. Rates of channel gradation processes and widening -- as determined from channel descriptions, discussions with local residents, and botanical evidence along the banks -- were used in conjunction with soil properties to estimate probable channel adjustments in the near future (10 to 20 years).

With the exception of a scour hole downstream from the highway crossing, the channel bed seems to have stabilized in the vicinity of State Highway 488 and channel-bed instability is not expected to pose a significant problem in the near future. The bankfull channel width in the vicinity of State Highway 488 could increase about 5 to 10 feet in the next 10 to 20 years. These projections are based on the assumption that no additional channel modifications and no unusually large destructive flooding will occur in the next 10 to 20 years.
\end{abstract}




\section{INTRODUCTION}

The Mississippi State Highway Department (MSHD) proposes to reconstruct the State Highway 488 crossing of Standing Pine Creek near Freeny, Miss. (fig. 1). Because channel degradation and bank sloughing have occurred recently on Standing Pine Creek and tributaries, the U.S. Geological Survey (USGS), in cooperation with the MSHD, visited this site during 1988 and 1991 to study channel and bank stability.

\section{Puxpose and Scope}

This report describes the existing channel-bed and channel-bank conditions and presents the results of a study to determine the potential for near-future ( 10 to 20 years) gradation processes and widening for Standing Pine Creek at State Highway 488 near Freeny in Leake County, Miss. Past and present channel-bed and channel-bank conditions were determined on the basis of field observations of channel-bed elevations, bank failures, ages and types of trees on the channel banks, and dry bulk-unit weights and shear-strength properties of bank material, which were used to evaluate the potential for bank failures. The potential for near-future gradation processes was analyzed by plotting available channel-bed elevations with time. The potential for near-future channel widening was estimated by using the potential for near-future bank failures based on recent (1988) channel geometry and dry bulk-unit weights and shear-strength properties of the bank material. This report is the sixth in a series of similar reports for selected stream crossings in Mississippi.

\section{General Description of Standing Pine Creek}

Standing Pine Creek is located in the North-Central Plateau, East Gulf Coastal Plain physiographic region (Thornbury, 1965). The drainage area of Standing Pine Creek at State Highway 488 is $57.3 \mathrm{mi}^{2}$; flood discharges from $18.7 \mathrm{mi}^{2}$ are controlled by five flood-retarding structures built by the U.S. Soil Conservation Service (SCS). The length of the principal channel upstream of the site is about $12.0 \mathrm{mi}$. Average channel and valley slopes in the vicinity of the crossing are about 2.8 and $4.5 \mathrm{ft} / \mathrm{mi}$, respectively. Standing Pine Creek flows into the Pearl River about $1.6 \mathrm{mi}$ downstream from the State Highway 488 crossing (fig. 1).

The Standing Pine Creek basin is underlain by the Sparta Sand of Tertiary age (about $175 \mathrm{ft}$ thick), which is composed mostly of sand, some silty sands, sandy clays, and clayey shales. Soil borings by the SCS at the site indicate an underlying clayey shale about $15 \mathrm{ft}$ below the existing channel bed (U.S. Soil Conservation Service, 1987). At State Highway 488, the channel bed is composed of uniform fine-grained sand, and the channel banks (average height about $10 \mathrm{ft}$ ) between about $100 \mathrm{ft}$ upstream and downstream from State Highway 488 are reinforced with riprap.

\section{Channel Modifications to Standing Pine Creek}

About 1917, the Standing Pine Creek Drainage District No. 1 excavated a 4.5-milong channel on Standing Pine Creek from about $5 \mathrm{mi}$ to about $9.5 \mathrm{mi}$ upstream from the State Highway 488 crossing to provide an outlet for farm drains and reduce flooding on crop lands in the drainage basin (Mississippi Board of Development, 1940).

By 1940, large quantities of sand and silt had been transported to the lower reaches of Standing Pine Creek and the channel, in places, was reported to have been virtually filled (Mississippi Board of Development, 1940). To alleviate the problem caused by this massive aggradation, a watershed work plan was prepared in 1965 for the Standing Pine Creek Drainage Basin under the authority of the Watershed Protection and Flood Prevention Act. The plan consisted of the following measures to reduce flooding:

- construction of six flood-water retarding structures;

- modifications of $21.8 \mathrm{mi}$ of channel to contain a cropping season flood with a 3-year recurrence interval; 


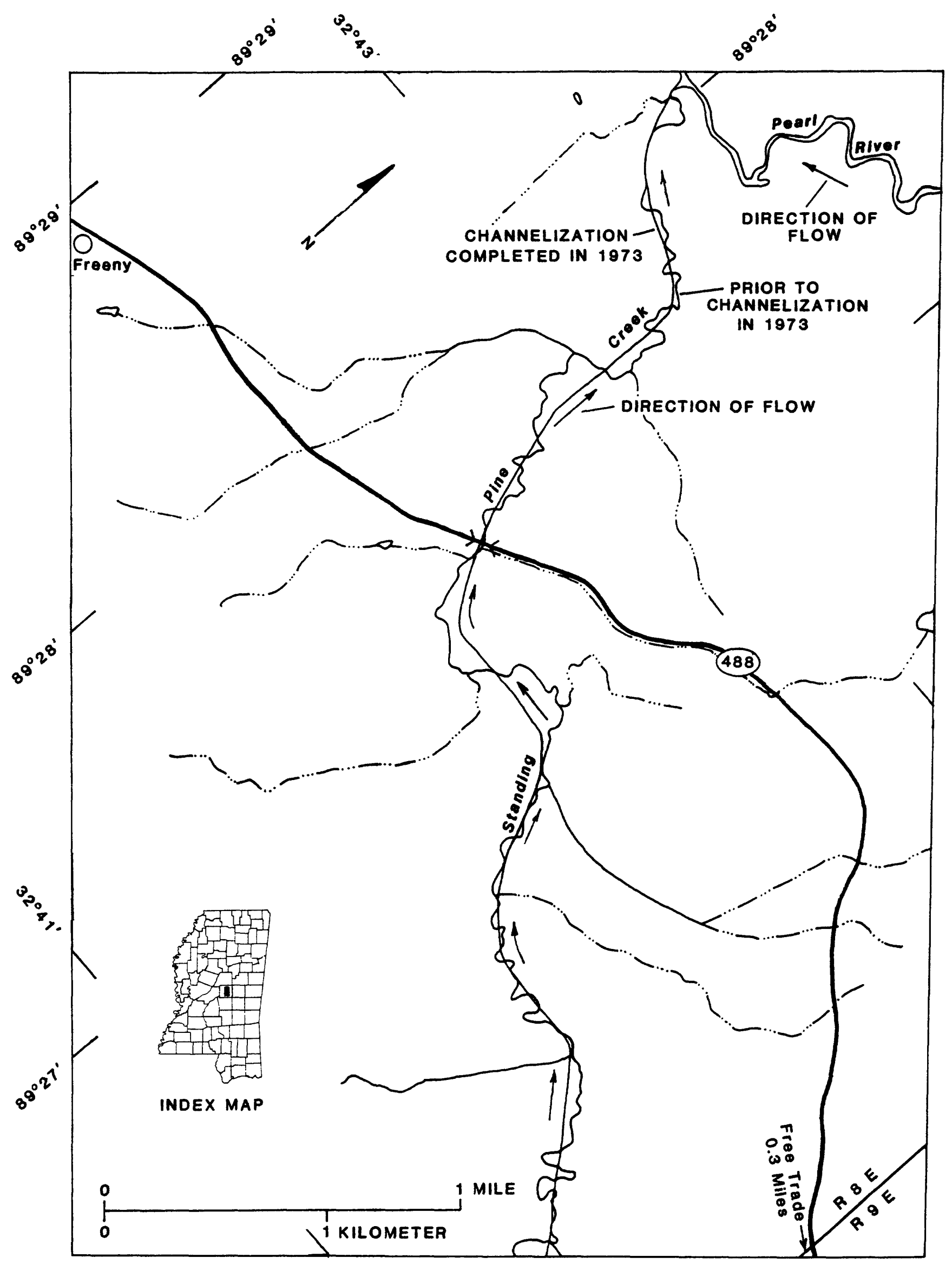

Figure 1.--Location of Standing Pine Creek at State Highway 488 near Freeny. 
- 72 corrugated metal pipe side inlets; and

- reinforcement of three bridges and bridge abutments along the mainstem of Standing Pine Creek.

The plan was supplemented in 1972 in response to growing concerns about the adverse environmental effects of channelization. The supplement included:

- deleting $0.36 \mathrm{mi}$ of channel improvement from the original plan on the downstream end of the main channel;

- reducing originally planned channel capacities by 42 percent;

- adding six wildlife-habitat structures (low water weirs) in the mainstream;

- constructing a 13-acre greentree reservoir; and

- adding a pipe overfall gradecontrol structure on a tributary at the upper end of the drainage basin.

Five of the six flood-water retarding structures and all planned channel improvement work have been completed as of 1991. Most of this work was completed by 1973. Between 1973 and 1978, the lower 2.0to 2.5-mi channel reach of Standing Pine Creek was dredged twice because of excessive aggradation (U.S. Soil Conservation Service, 1987).

For the purposes of this report, the 1973 design specifications were used to determine changes in the channel because few data are available that describe the channelization performed upstream of the site in 1917.

\section{Acknowledgments}

The authors are indebted to members of the Mississippi State Highway Department, Hydraulics Division, who provided bridgeinspection records and to members of the Department's Soil Mechanics Laboratory, who assisted in the analysis of soil samples. The authors also acknowledge the valuable guidance and technical assistance of Phillip Jones and Tyler Smith of the U.S. Soil
Conservation Service, who provided channel cross sections and profiles and information on soils and channel evolution processes on Standing Pine Creek.

\section{CHANNEL-BED STABILITY}

\section{Profiles}

Three channel-bed profiles $(1973,1978$, and 1987) for Standing Pine Creek (fig. 2) were obtained from the SCS for use in this study. Standing Pine Creek aggraded from 1973 to 1987 from the mouth to about $8,000 \mathrm{ft}$ upstream and degraded farther upstream; however, the channel reach from the mouth to about 11,000 to $13,000 \mathrm{ft}$ upstream filled between 1973 and 1978 and was dredged twice (U.S. Soil Conservation Service, 1987). Therefore, the profiles in figure 2 do not actually show the full magnitude of aggradation that occurred between 1973 and 1987 in the lower channel reaches. The headward progressing channel-bed degradation has decreased the channel gradient with time in the lower 7 or 8 miles of the stream (fig. 2), thus, decreasing the stream power. This reduction in stream power, in turn, reduces the amount of bed material that the stream is capable of transporting. The average channel bed slope in the vicinity of State Highway 488 decreased from about $5.6 \mathrm{ft} / \mathrm{mi}$ in 1973 to about $2.8 \mathrm{ft} / \mathrm{mi}$ in 1987 . The channel bed slope in 1987 also seems to be representative of the 1991 slope.

Channel-bed profiles obtained in 1987, 1988 , and 1991 indicate a scour hole in the vicinity of State Highway 488 (fig. 3). The minimum bed elevations obtained in the scour hole were $237.5,239.1$, and $234.8 \mathrm{ft}$ for the 1987, 1988, and 1991 surveys, respectively. The most accurate measurement of minimum bed elevation in the scour hole was obtained in 1991 by personnel of the USGS using a fathometer attached to a boat. The 1987 and 1988 profiles were limited to wadable depths, and therefore, the minimum bed elevations obtained are probably somewhat higher than the actual minimum bed elevation at the time of the surveys. From the 1991 profile, the scour hole is a maximum of $8.4 \mathrm{ft}$ deep (about $200 \mathrm{ft}$ downstream from 


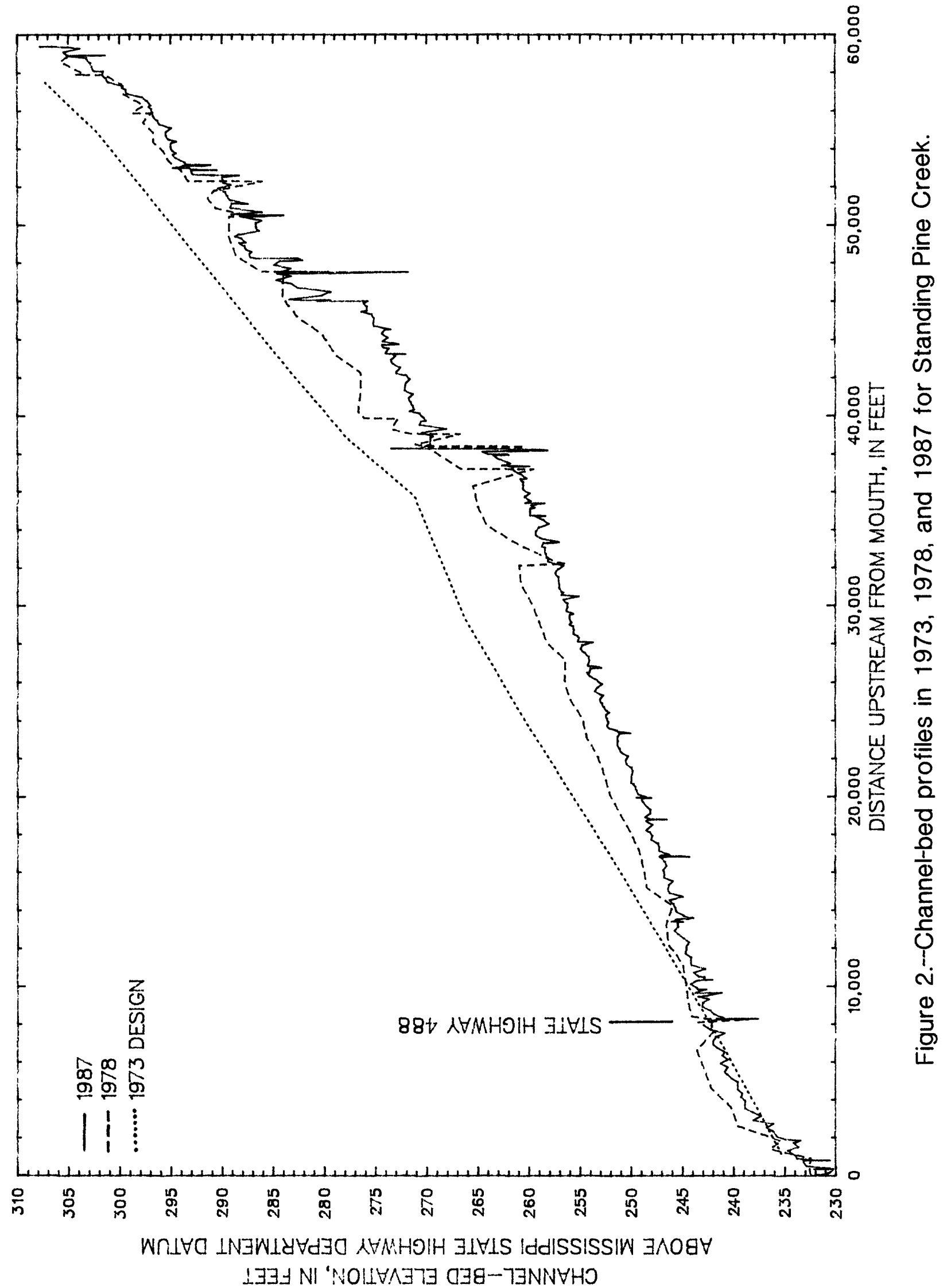




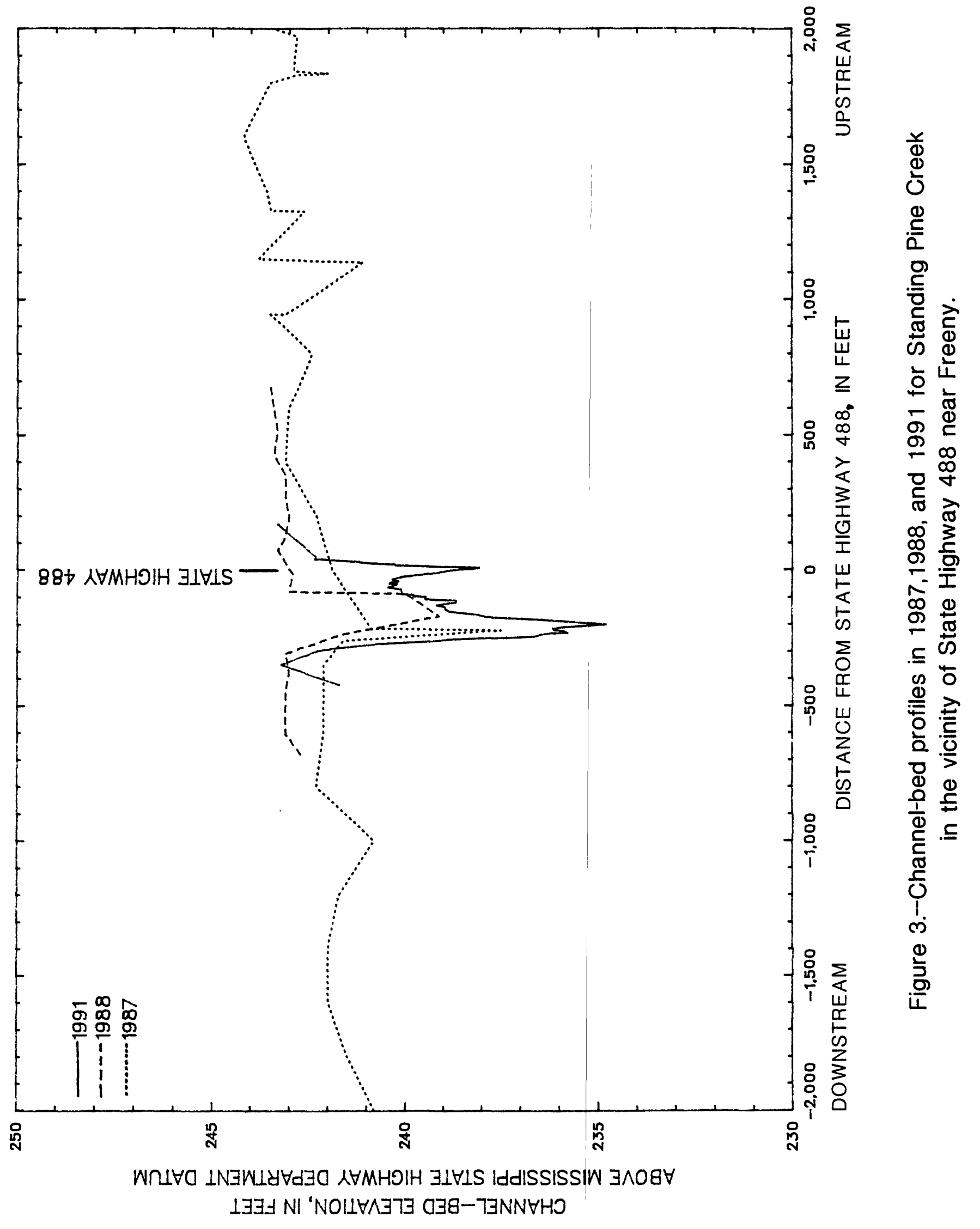


State Highway 488) and about $520 \mathrm{ft}$ in length. It appears that between 1987 and 1988, the hole scoured longitudinally. Between 1988 and 1991, the hole also appears to have scoured longitudinally, probably due to flooding in 1991.

\section{Gradation Analyses}

Channel-gradation processes on an alluvial stream undergoing morphologic change in response to channel modifications generally start at a high rate and diminish with time. Studies of channel-gradation processes on alluvial streams have shown that channel-bed elevation can be expressed as a power function with time (Simon and Hupp, 1986a).

Average channel-bed elevations for Standing Pine Creek at State Highway 488 were obtained from surveys and inspections by the USGS, the MSHD, and the SCS (table 1). Some differences in channel-bed elevations may not be indicative of actual change. The channel-bed elevations used to analyze gradation processes were obtained on the edges of the local scour hole in the vicinity of the State Highway 488 bridge as shown in figure 3. As determined from field observations, channel profiles, and cross sections, the scour hole in the vicinity of State Highway 488 has a significant effect on the channel-bed elevation at the State Highway 488 bridge but not on elevations representative of the channel-bed slope for the channel reach upstream and downstream.

The channel bed at State Highway 488 seems to have aggraded more than $2 \mathrm{ft}$ from 1973 (when channelized) to 1978 (fig. 2), but the crossing is located in a channel reach that was dredged twice between 1973 and 1978 (U.S. Soil Conservation Service, 1987). The channel bed in the vicinity of State Highway 488 aggraded from 1973 to 1978, but to a much greater extent than the available elevations indicate. The elevations for 1978, 1985-88, and 1991 indicate only about $1.5 \mathrm{ft}$ of degradation from 1978 to 1991 (fig. 4). A flood with about a 25-year recurrence interval occurred in April 1979 on Standing Pine Creek and probably scoured the channel bed, but the extent of the scour is unknown. Channel-bed shifts are likely even during moderate flows because the channel bed consists mostly of fine-grained sand. Due to these factors, channel-bed gradation

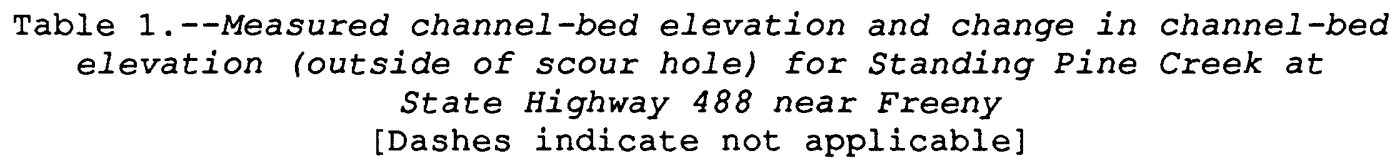

\begin{tabular}{lcc}
\hline Year & $\begin{array}{c}\text { Average } \\
\text { channel-bed elevation } \\
\text { (feet) }\end{array}$ & $\begin{array}{c}\text { Total change in channel-bed } \\
\text { elevation since } 1973 \\
\text { (feet) }\end{array}$ \\
1959 & 244.6 & -- \\
1961 & 248.0 & -- \\
1970 & 247.0 & -- \\
1973 & 241.9 & 0 \\
1978 & 244.7 & +2.8 \\
1985 & 243.8 & +1.9 \\
1986 & 243.4 & +1.5 \\
1987 & 243.3 & +1.4 \\
1988 & 243.3 & +1.4 \\
1991 & b243.2 & +1.3 \\
& & \\
\hline
\end{tabular}

a Design elevation.

b Average elevation at upstream and downstream edges of scour hole. 


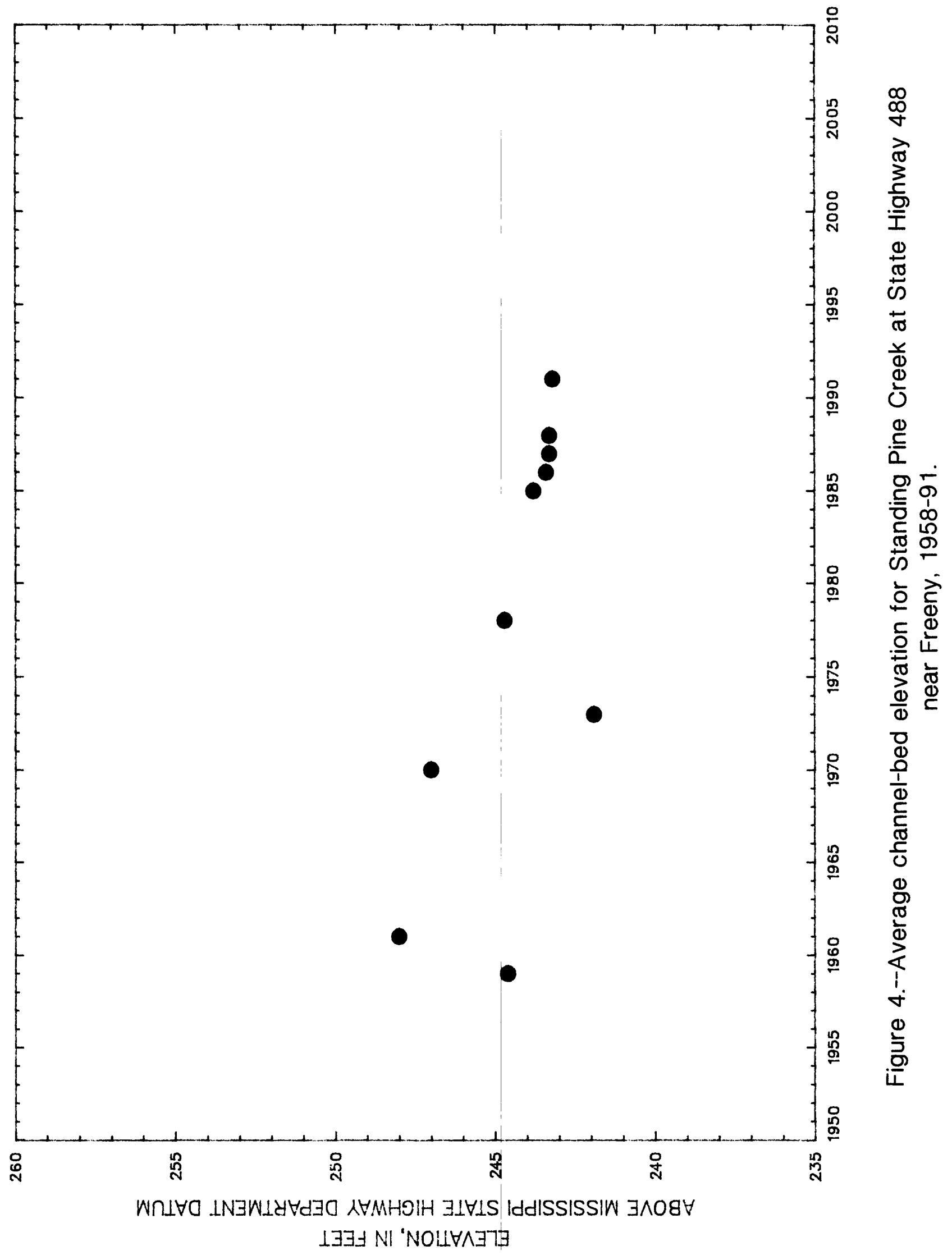


processes were not expressed as a power function with time. Based on the available bed elevations, the channel bed seems to be near equilibrium in the vicinity of State Highway 488; this conclusion is supported by field observations in 1988 and 1991. The 1991 elevation is only $1.3 \mathrm{ft}$ higher than the 1973 elevation and, therefore, aggradation is not expected to pose a severe problem at this site in the near future. These assumptions could be negated by additional channel modifications or the occurrence of unusually large destructive flooding, which could alter ongoing gradation processes.

\section{CHANNEL-BANK STABILITY}

\section{Evidence of Widening}

Channel cross sections surveyed between 1973 and 1991 and botanical evidence of recent bank failures were used to determine amounts of bank widening since 1973, when Standing Pine Creek was channelized. These data were collected in a reach from about $2,500 \mathrm{ft}$ upstream to about $6,000 \mathrm{ft}$ downstream of the State Highway 488 crossing of Standing Pine Creek.

\section{Cross Sectional Evidence}

Channel cross sections for Standing Pine Creek were surveyed by the SCS in 1973 (after channelization), 1978, and 1987, and by the MSHD in the vicinity of State Highway 488 in 1988, and by the USGS in 1988 and 1991 . There were no significant changes in channel width between 1987 and 1991 in the vicinity of State Highway 488. The existing average bankfull channel width is about $107 \mathrm{ft}$ in the channel reach located 500 to $6,000 \mathrm{ft}$ downstream of the bridge, about $70 \mathrm{ft}$ at the bridge where banks are reinforced with riprap, and about $124 \mathrm{ft}$ in the channel reach located 200 to $2,500 \mathrm{ft}$ upstream of the bridge. The 1973 design bankfull channel width was about $70 \mathrm{ft}$ for the channel reach in the vicinity of the bridge. Differences between the existing widths and the design width may be because the meanders were taken out when the reach was channelized (fig. 1) and, therefore, the 1973 width was probably greater than $70 \mathrm{ft}$ in some places. From 1978 to 1987, the channel width remained about the same for the downstream reach and increased an average of about $15 \mathrm{ft}$ for the upstream reach.

\section{Botanical Evidence}

Bank failures along unstable reaches may kill, tilt, or scar existing woody plants, and result in fresh surfaces on banks on which plants may become established. Scars and sprouts from parental stems of tilted plants yield accurate (within 1 year, often within one season) dates of bank failure (Hupp, 1987, 1988; Sigafoos, 1964).

Eccentric growth, resulting in anomalous tree-ring series, occurs when the tree stem is inclined. This type of growth is easily determined from tree cross sections where concentric-ring formation abruptly shifts to the eccentric because ring width is greater in the upslope direction than in the downslope direction. Eccentric-ring patterns yield highly accurate dates, usually accurate within one season, of tilting. Dating of stems that have established on disturbed surfaces yields minimum ages for the surfaces (Simon and Hupp, 1986b).

Ages of trees growing on bank surfaces along Standing Pine Creek near State Highway 488 indicate that most of the recent bank widening occurred as a result of the April 1979 flood. Botanical data were collected by taking cross sections or increment borings of sprouts from tilted trees and of saplings and mature trees (such as catalpa, sycamore, willow, and alder) on the channel banks to determine their ages (table 2). The average failure-block width was about $7 \mathrm{ft}$ and, since the April 1979 flood and the 1978 dredging of the channel bed, trees have grown below top of bank on channel banks and currently armor the banks. It should be noted that previous bank failures may have been obscured with time and (or) by succeeding large floods (Simon and Hupp, 1986b). 
Table 2.--Botanical data collected in 1988 on Standing Pine Creek in the vicinity of State Highway 488 near Freeny

[Dashes indicate data not available]

\begin{tabular}{|c|c|c|c|c|}
\hline \multirow{2}{*}{\multicolumn{2}{|c|}{$\begin{array}{c}\text { Distance from bridge } \\
\text { (feet) }\end{array}$}} & \multicolumn{2}{|c|}{$\begin{array}{c}\text { Failure-block width } \\
\text { (feet) }\end{array}$} & \multirow{3}{*}{ Description of } \\
\hline & & \multirow{2}{*}{$\begin{array}{c}\text { left (west) } \\
\text { bank }\end{array}$} & \multirow{2}{*}{$\begin{array}{c}\text { right (east) } \\
\text { bank }\end{array}$} & \\
\hline upstream & downstream & & & \\
\hline-- & 500 & -- & -- & $\begin{array}{l}\text { 10-year old willows } \\
\text { and } 7-\text { to } 8 \text {-year old } \\
\text { alders on left and } \\
\text { right upper banks }\end{array}$ \\
\hline 150 & -- & -- & 8 & $\begin{array}{l}6 \text { - to } 7 \text {-year old } \\
\text { catalpa on right bank } \\
\text { indicating minimum } \\
\text { age of slough }\end{array}$ \\
\hline 250 & -- & -- & -- & $\begin{array}{l}\text { 16- to } 20 \text {-year old } \\
\text { willows and sycamores } \\
\text { on right upper bank }\end{array}$ \\
\hline 500 & -- & 7 & 6 & $\begin{array}{l}\text { No trees dated but } \\
\text { did not appear to be } \\
\text { recent }\end{array}$ \\
\hline 600 & -- & -- & -- & $\begin{array}{l}\text { 10-year old sycamore } \\
\text { at toe of left bank }\end{array}$ \\
\hline
\end{tabular}

\section{Stability Analyses}

Shear-strength properties of the channel banks were determined on the right (east) bank of Standing Pine Creek about $120 \mathrm{ft}$ downstream from State Highway 488 with the Iowa Borehole Shear Tester ${ }^{1}$ (BST) (Handy and Fox, 1967). Dry bulk-unit weights and shear-strength properties of soils obtained at the site are listed in table 3. The average moisture content of the soils was about 22 percent.

Shear-strength data obtained using the BST compared reasonably well with the results of triaxial shear-strength tests that were made by the MSHD. BST results for

\footnotetext{
$1_{\text {The use of trade or product names in this report is for }}$ identification purposes only, and does not constitute endorsement by the U.S. Geological Survey.
}

individual soil strata were used in the stability analyses.

The factor of safety used in describing channel-bank stability is the ratio of the resisting force (shear-strength of the bank material) to the driving force (weight of the bank material). Therefore, if the resisting force is equal to the driving force, then the factor of safety is 1.0. Theoretically, when the factor of safety is less than 1.0, failure occurs; when it is greater than 1.0, failure does not occur. This is based on the assumption that all the forces are considered. A factor of safety of at least 1.5 generally is used in design. Factors of safety for bank failures for selected percentages of bank saturation were determined by bankstability analyses using dry bulk-unit weights and shear-strength properties of the bank material at cross sections surveyed in 1988. These cross sections were located $100 \mathrm{ft}$ 
upstream and downstream from State Highway 488 and at State Highway 488 (banks reinforced with riprap). An angle of internal friction of 38 degrees and a dry bulkunit weight of $160 \mathrm{lb} / \mathrm{ft}^{3}$ was used for the riprap revetment under the State Highway 488 bridge. Computer programs REAME (Rotational Equilibrium Analysis of Multilayered Embankments) and SWASE (Sliding Wedge Analysis of Sidehill Embankments) developed by Huang (1983) and UTEXAS2 (University of Texas Analysis of Slopes-Version 2) developed by Wright (1986) were used in the analyses. The analyses included an iterative search to determine the minimum factor of safety for each percentage of bank saturation.

Analysis of both planar and rotational bank failures indicated rotational bank failures were more critical. Factors of safety for 0-percent bank saturation ranged from 2.42 on the left (west) bank of the cross section located $100 \mathrm{ft}$ upstream from the State Highway 488 bridge to 1.85 at the left and right (east) banks of the cross section at the bridge. Factors of safety for 100-percent bank saturation ranged from 1.80 on the right bank of the cross section located $100 \mathrm{ft}$ upstream from the bridge to 1.20 at the left and right banks of the cross section at the bridge.

The critical rotational-failure surfaces for 0 - and 100-percent bank saturation for the channel cross sections surveyed in 1988 are shown in figures 5, 6, and 7. Failure-block widths on the right and left banks at the upstream cross section are about 4 and $7 \mathrm{ft}$, respectively (fig. 5); widths on the right and left banks downstream are about 9 and $5 \mathrm{ft}$, respectively (fig. 7). The average failureblock width of about $6 \mathrm{ft}$ agreed reasonably well with the average width of about $7 \mathrm{ft}$ observed in the field. For the cross section located at the bridge (fig. 6), the critical failure surface intersects the ground at and below top of bank. This is probably because of the added weight of the riprap reinforcement in the upper part of the bank.

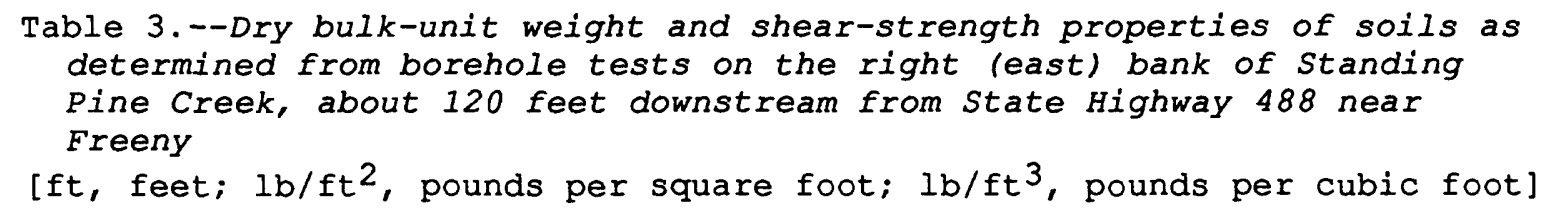

\begin{tabular}{lcccc}
\hline $\begin{array}{c}\text { General } \\
\text { soil description }\end{array}$ & $\begin{array}{c}\text { Bore hole } \\
\text { depth } \\
(\mathrm{ft})\end{array}$ & $\begin{array}{c}\text { Dry } \\
\text { bulk-unit } \\
\text { weight } \\
\left(1 \mathrm{~b} / \mathrm{ft}^{3}\right)\end{array}$ & $\begin{array}{c}\text { Cohesion } \\
\left(1 \mathrm{~b} / \mathrm{ft}^{2}\right)\end{array}$ & $\begin{array}{c}\text { Angle of } \\
\text { internal } \\
\text { friction } \\
\text { (degrees) }\end{array}$ \\
\hline $\begin{array}{l}\text { Brown-white sand } \\
\text { Orange-gray, } \\
\text { sandy clay }\end{array}$ & $0-2.7$ & 92 & 59 & 32 \\
$\begin{array}{c}\text { Gray-brown } \\
\text { sandy clay } \\
\text { (organics) }\end{array}$ & $3.7-3.6$ & 109 & 235 & 35 \\
$\begin{array}{c}\text { Brown sandy clay } \\
\text { (organics) }\end{array}$ & $5.2-8.5$ & 91 & 235 & 35 \\
$\begin{array}{c}\text { Brown-gray, } \\
\text { silty clay }\end{array}$ & $8.5-10.5$ & 94 & 281 & 23 \\
\hline
\end{tabular}




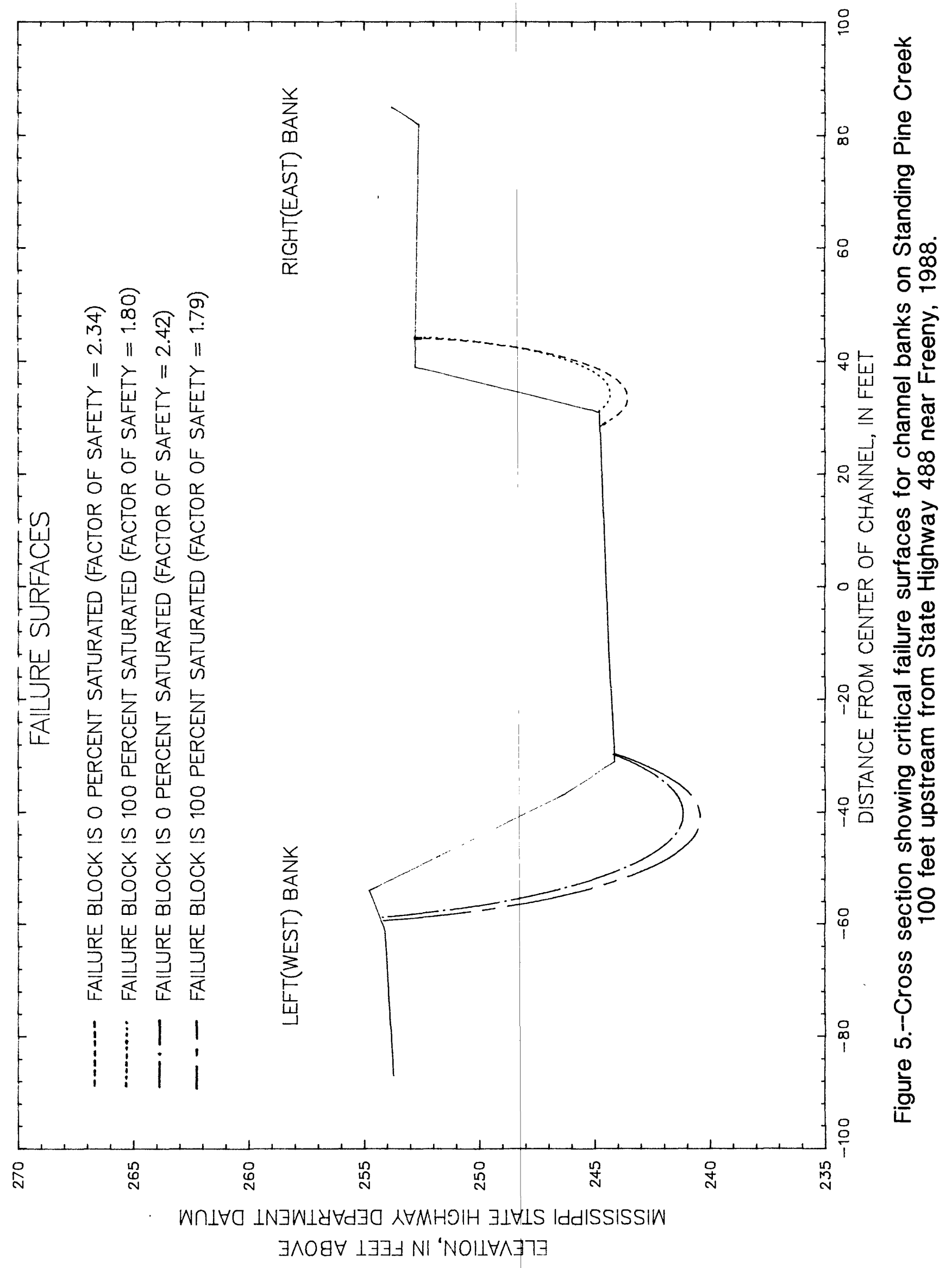




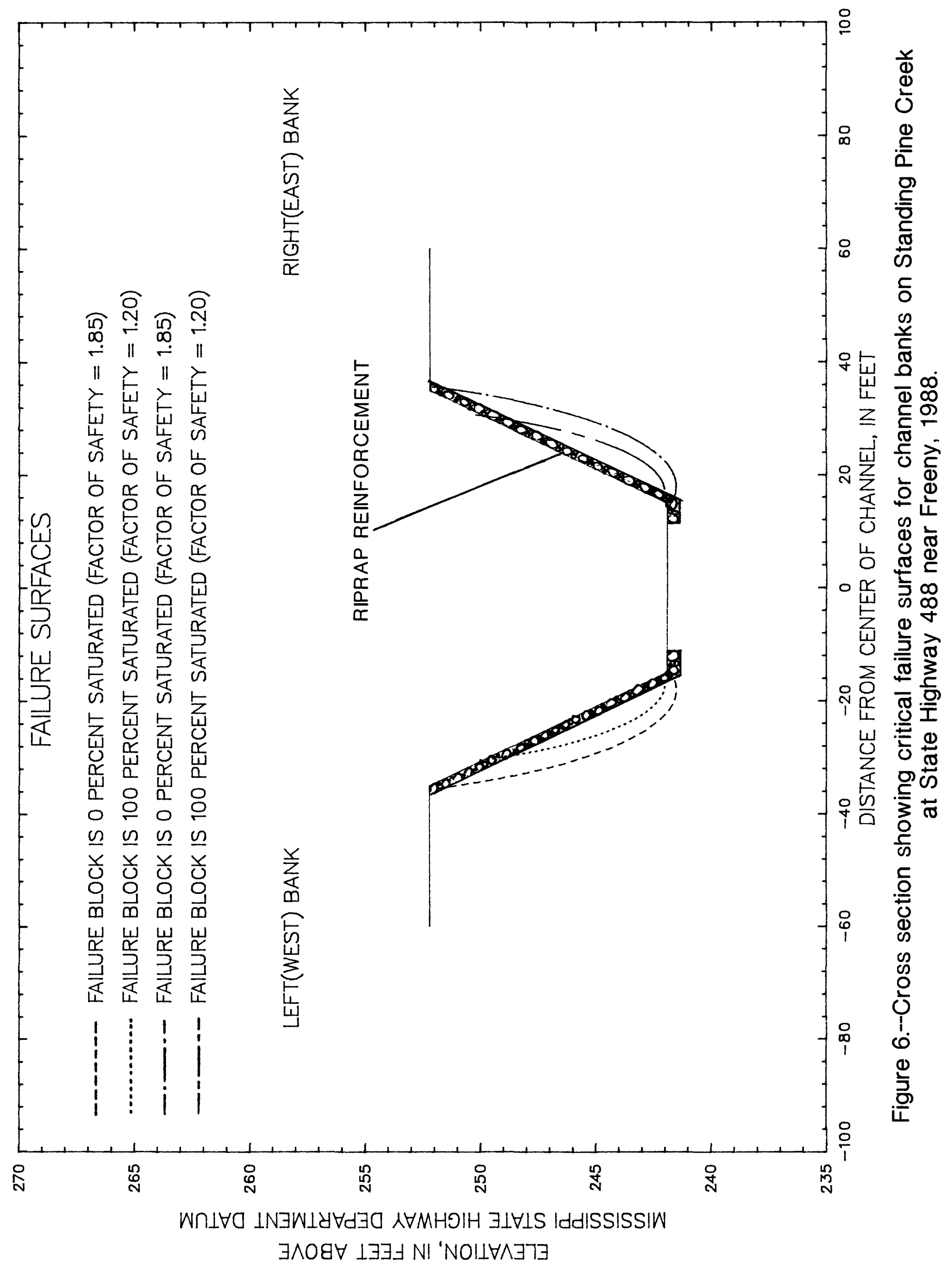




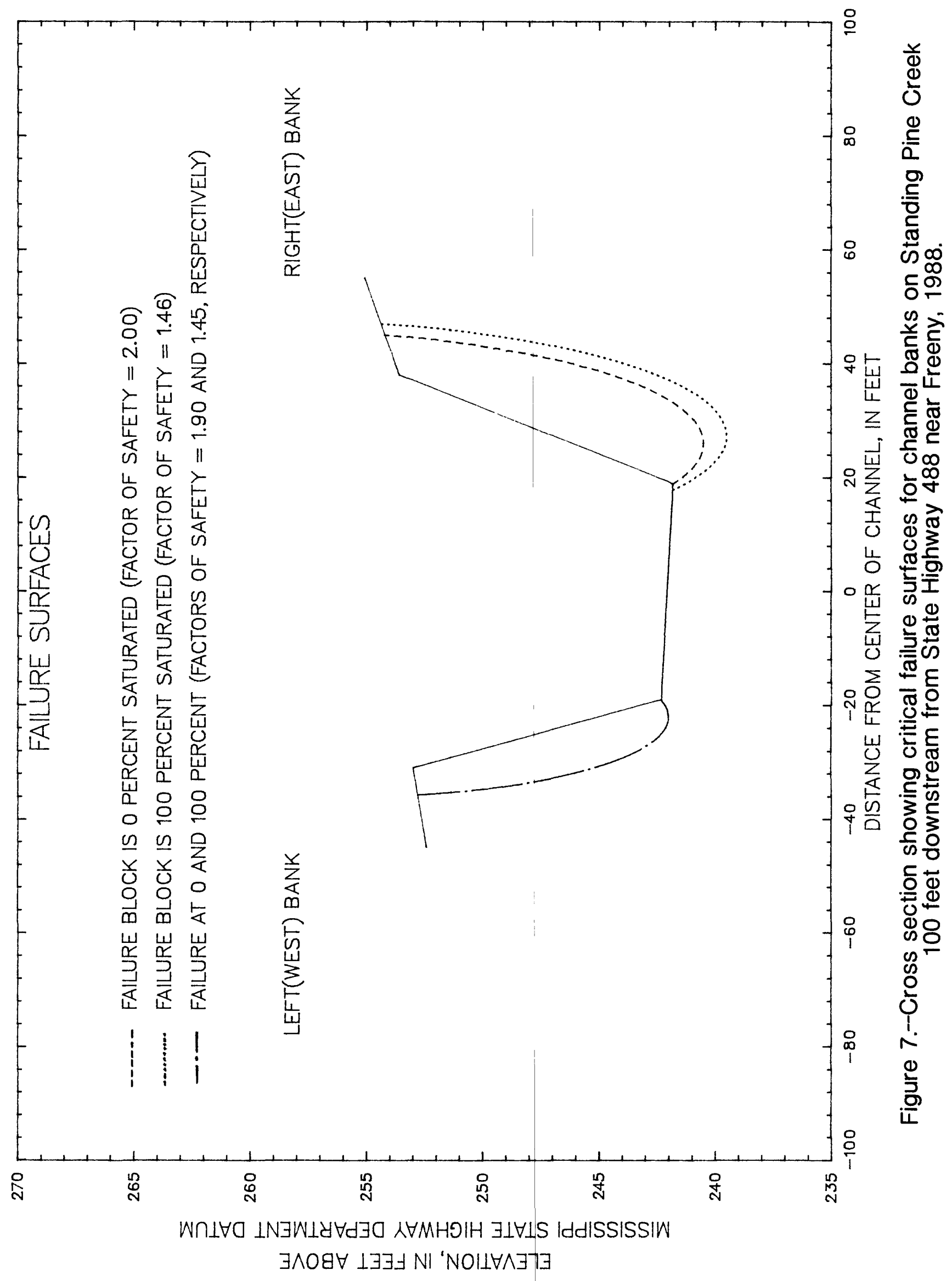


In 1991, field observations of the channel reach between $100 \mathrm{ft}$ downstream and $100 \mathrm{ft}$ upstream from the bridge indicated some minor failures of riprap in the lower part of the banks at the bridge where the underlying geotextile lining is exposed. In 1991, the scour hole extended through the bridge. Average bed elevation was about 2,3, and 1 $\mathrm{ft}$ lower than the 1988 bed elevation at the cross section located $100 \mathrm{ft}$ downstream, at the bridge, and $100 \mathrm{ft}$ upstream, respectively. Factors of safety were recomputed by lowering the bed at each cross section. Minimum factors of safety for 100-percent bank saturation were computed to be 1.18 at $100 \mathrm{ft}$ downstream, 1.18 at the bridge, and 1.48 at $100 \mathrm{ft}$ upstream from the bridge. The factors of safety were lowered by using lower channel-bed elevations, but there were no significant differences in failure surfaces shown in figures 5,6 , and 7 .

\section{Widening Analyses}

Estimates of near-future (10 to 20 years) channel widening can be obtained at many sites by projecting the streambank sloughline angle on a plotted cross section (Simon and Hupp, 1986b). Extension of the slough line was not used for the State Highway 488 crossing, however, because slough lines at the site are not well established. A temporary angle of stability was estimated for each bank in each available cross section by averaging the existing bank angle and the angle of internal friction of the bank material, a technique developed by Spangler and Handy (1973). Estimates of near-future channel widening were made by extending the temporary angle of stability (figs. 8, 9). This indicates that the bankfull channel width could increase about $3 \mathrm{ft}$ at the cross section located about $100 \mathrm{ft}$ upstream of the crossing and about 5 to $10 \mathrm{ft}$ at the cross section located $100 \mathrm{ft}$ downstream of the crossing. Widening analysis at the bridge was omitted because of the riprap reinforcement of the banks. Channelwidening processes in the past are assumed to be representative of those in the near future. This assumption could be negated by additional channel modifications or the occurrence of unusually large, destructive flooding that could alter ongoing widening processes.

\section{SUMMARY}

The channel bed of Standing Pine Creek at State Highway 488 was about $1 \mathrm{ft}$ higher in 1991 than when the reach was channelized in 1973. Aggradation in this reach between 1973 and 1978 probably exceeded $1 \mathrm{ft}$ because the channel was dredged twice during this period. Aggradation since 1978 has been relatively small. From 1978 to 1991, the bankfull channel width has remained about the same at the bridge and in the channel reach located 500 to $6,000 \mathrm{ft}$ downstream of the bridge. Rates of channel gradation processes and widening -- as determined from channel descriptions, discussions with local residents, and botanical evidence along the banks -were used in conjunction with soil properties to estimate probable channel adjustments in the near future (10 to 20 years). Bankfull channel widths have increased an average of about $15 \mathrm{ft}$ in the channel reach located 200 to $2,500 \mathrm{ft}$ upstream of the bridge. The average channel bed slope in the vicinity of State Highway 488 decreased from about 5.6 $\mathrm{ft} / \mathrm{mi}$ in 1973 to about $2.8 \mathrm{ft} / \mathrm{mi}$ in 1987 . The channel-bed slope in 1991 seems to be about the same as that in 1987. Based on botanical evidence, most recent bank failures appeared to have occurred as a result of the April 1979 flood. With the exception of a local scour hole downstream from the crossing, the channel bed seems to have stabilized with perhaps some gradual aggradation in the vicinity of State Highway 488, which is not expected to pose a severe problem at this site in the near future. Channel-bed shifts are likely even during moderate flows because the bed consists mostly of fine-grained sand. The bankfull channel width could increase about 5 to $10 \mathrm{ft}$ in the next 10 to 20 years in the vicinity of State Highway 488. These projections are based on the assumption that no additional channel modifications and no unusually large and destructive flooding will occur by the year 2010 . 


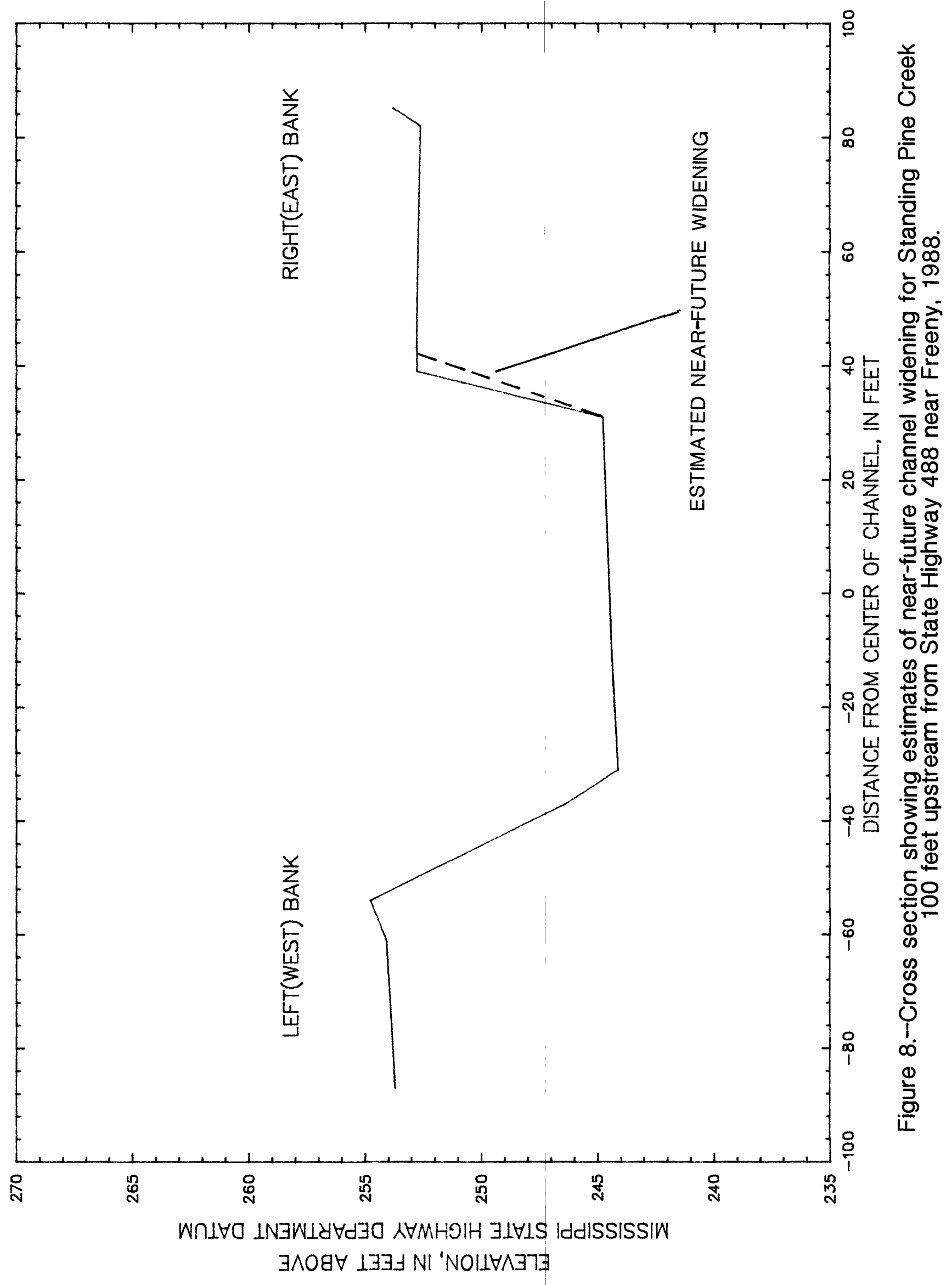




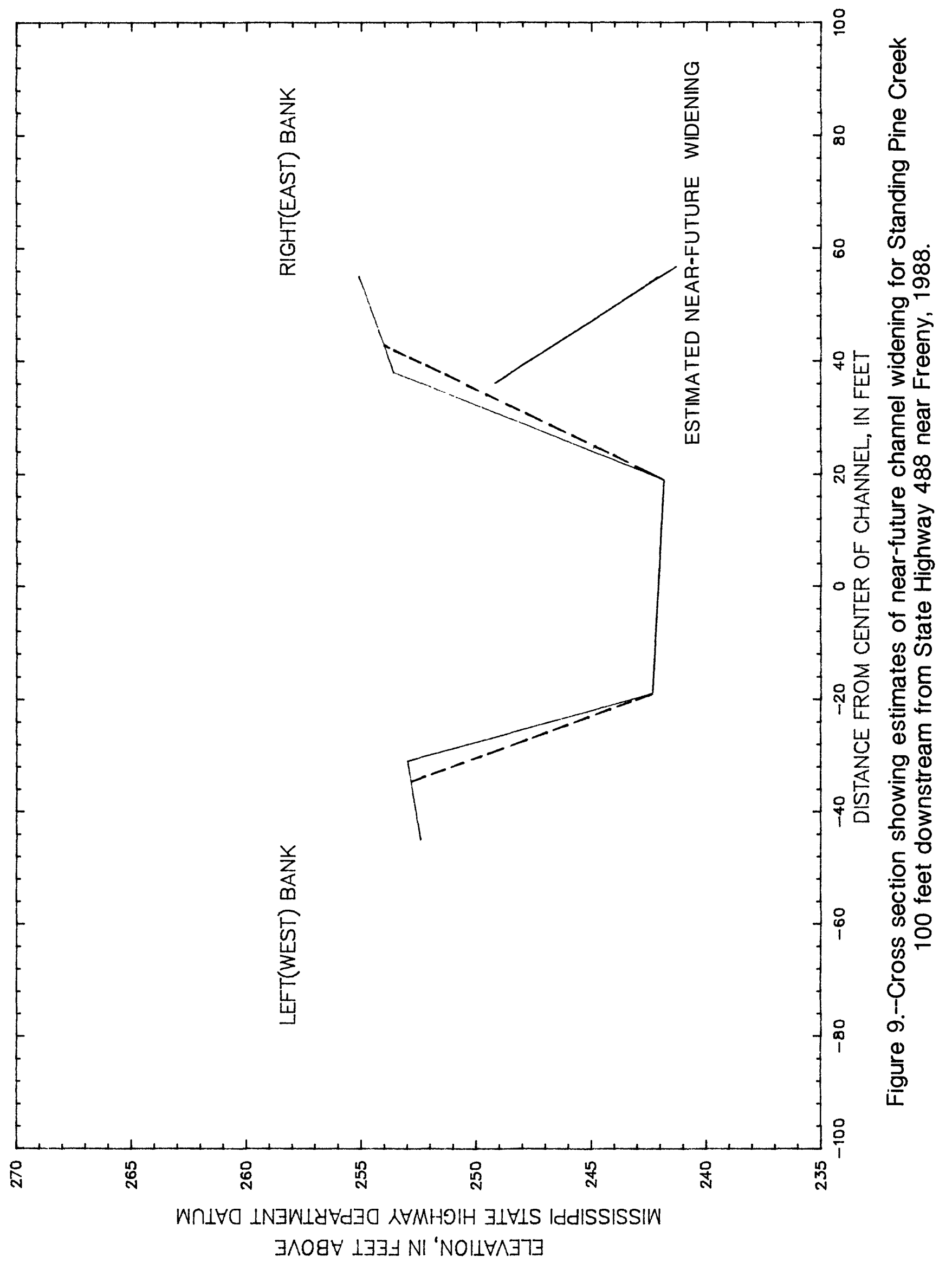




\section{REFERENCES}

Cernica, J.N., 1982, Geotechnical engineering: CBS College Publishing, $488 \mathrm{p}$.

Das, B.M., 1984, Principles of foundation engineering: Wadsworth, Inc., $595 \mathrm{p}$.

Handy, R.L., 1981, Borehole shear test, instructions version 9-81: Ames, Iowa, Handy Geotechnical Instruments, Inc., $26 \mathrm{p}$.

Handy, R.L., and Fox, N.W., 1967, A soil bore-hole direct-shear device: Highway Research News No.27, p. 4251.

Huang, Y.H., 1983, Stability analysis of earth slopes: Van Nostrand and Co., $305 \mathrm{p}$.

Hupp, C.R., 1987, Determination of bank widening and accretion rates and vegetation recovery along modified West Tennessee streams in International Symposium Proceedings of Ecological Aspects of Tree-Ring Analysis: Department of Energy Conference 8608144, p. 224-233.

-----1988, Plant ecological aspects of flood geomorphology and paleoflood history: Flood Geomorphology, John Wiley and Sons, Inc., p. 335-356.

Mississippi Board of Development, 1940, Standing Pine Creek Drainage District No. 1, Leake County, Mississippi: W.P.A. Project No. 5483, Statewide Drainage Survey, $8 \mathrm{p}$.

Sigafoos, R.S., 1964, Botanical evidence of floods and floodplain deposition: U.S. Geological Survey Professional Paper 485-A, p. A1-A33.
Simon, Andrew, and Hupp, C.R., 1986a, Channel evolution in modified Tennessee channels: Federal Interagency Sedimentation Conference, 4th, Las Vegas, Nevada, 1986, Proceedings, v. 2, p. 5-71 to 5-82.

---1986b, Channel widening characteristics and bank slope development along a reach of Cane Creek, West Tennessee, in Subitzky, Seymour, ed., Selected papers in the hydrologic sciences: U.S. Geological Survey Water-Supply Paper 2290, p. 113-126.

Sowers, G.F., 1979, Introductory soil mechanics and foundations: Geotechnical engineering (4th ed.): MacMillan Publishing Co., Inc., 621 p.

Spangler, M.G., and Handy, R.L., 1973, Soil engineering (3rd ed.): New York and London, Intext Educational, $748 \mathrm{p}$.

Thornbury, W.E., 1965, Regional geomorphology of the United States: John Wiley and Sons, Inc., $609 \mathrm{p}$.

U.S. Soil Conservation Service, 1987, Deficiency report supplement, Standing Pine Creek Watershed Stability plan based on geomorphic evaluation: Unpublished data on file in Jackson, Mississippi, office of the U.S. Soil Conservation Service, $50 \mathrm{p}$.

Wright, 1986, UTEXAS2 (University of Texas Analysis of Slopes - Version 2): A computer program for slope-stability calculations: Geotechnical Engineering Software GS86-a, 109 p. 